\title{
Evaluation of visual encounter surveys of the noble crayfish, Astacus astacus, and the spiny-cheek crayfish, Orconectes limosus
}

\author{
Maciej Bonk, Rafał Bobrek, Jacek Dołęga, Witold Strużyński
}

Received - 20 March 2019/Accepted - 03 June 2019. Published online: 30 June 2019; @Inland Fisheries Institute in Olsztyn, Poland Citation: Bonk M., Bobrek R., Dołęga J., Strużyński W. 2019 - Evaluation of visual encounter surveys of the noble crayfish, Astacus astacus, and the spiny-cheek crayfish, Orconectes limosus - Fish. Aquat. Life 27: 112-117.

\begin{abstract}
Several methods of sampling are commonly used to detect freshwater crayfish (Decapoda: Malacostraca). Many of them are laborious, time-consuming, and require dedicated equipment. The aims of this contribution are i) to compare visual encounter surveys and baited trap success in the detection of the noble crayfish, Astacus astacus (L.), which is endangered in Poland, and ii) to assess the time needed to detect the invasive spiny-cheek crayfish, Orconectes limosus (Raf.). The study is based on data collected between 2016-2018 in various habitats of Astacus astacus and Orconectes limosus in Poland. Visual encounter surveys are at least as effective in assessing the presence of $A$. astacus as the trapping method. The modal value for the detection time of $O$. limosus at all sites and all surveys was two minutes. Sample
\end{abstract}

M. Bonk[ $\risingdotseq]$

Institute of Nature Conservation, Polish Academy of Sciences

al. Adama Mickiewicza 33, 31-120 Kraków, Poland

e-mail: bonk@iop.krakow.pl

R. Bobrek

Polish Society for the Protection of Birds

ul. Odrowąża 24, 05-270 Marki, Poland

J. Dołęga

University of Agriculture in Cracow

Department of Ichthyobiology and Fisheries

ul. Spiczakowa 6, 30-199 Kraków-Mydlniki, Poland

\section{W. Strużyński}

Warsaw University of Life Sciences SGGW

Division of Zoology, Department of Animal Environment Biology,

Animal Sciences Faculty

02-786 Warsaw, Poland rarefaction showed that one survey covered $11.33(\mathrm{SD}=0.43)$ of a maximum of 12 detections per survey. This suggests that, despite some limitations, visual detection might be an efficient method for determining crayfish presence/absence for a wide range of applications.

Keywords: crayfish sampling, watercourses, water reservoirs, lakes, baited traps

\section{Introduction}

Several sampling methods are commonly used to detect freshwater crayfish (Decapoda: Malacostraca). These include baited minnow or eel traps, light attraction, electrofishing, kick sampling, seining, snorkeling, and artificial refuge traps (Rabeni et al. 1997, Alonso 2001, Pilotto et al. 2008, Price and Welch 2009, Ahmadi 2016, Green et al. 2018). These methods usually provide an indirect population assessment, but they can be used to assess total population abundance when applied with capture-mark-recapture methods (Nowicki et al. 2008). Comparisons of some of these methods were conducted to determine the best sampling methods for specific habitats and species (Dorn et al. 2005, Price and Welch 2009). However, these methods are laborious, time consuming, and require dedicated equipment. For example, baited traps should be exposed

(c) Copyright by Stanisław Sakowicz Inland Fisheries Institute in Olsztyn.

C 2019 Author(s). This is an open access article licensed under the Creative Commons Attribution-NonCommercial-NoDerivs License (http://creativecommons.org/licenses/by-nc-nd/3.0/). 
at night for at least several hours (Holdich and Black 2007, Strużyński 2015). These can negatively affect efficiency, because of the reduced number of sites that can be studied within a given time unit. Simple methods providing presence/absence data are also useful for determining crayfish distribution and, to some extent, to study their ecology. Potentially, the simplest presence/absence method is wading in the shallow water and actively, visually searching for crayfish in the beam of a flashlight. The aims of this contribution are i) to compare visual encounter surveys and baited trap success in the detection of the noble crayfish, Astacus astacus (L.), which is endangered in Poland, and ii) to assess the time needed to detect the invasive spiny-cheek crayfish, Orconectes limosus (Raf.).

\section{Methods}

\section{Astacus astacus}

Data were obtained from national monitoring of the noble crayfish in Poland in which the authors of this paper were the main field workers. The detailed sampling protocol is described in a methodological guide book (Strużyński 2015). The method is based on sampling river sections of $1 \mathrm{~km}$ or parts of the shoreline in stagnant waters. In each section, ten baited traps are placed in a way that maximizes crayfish detection (i.e., upstream sites providing shelter). Trap exposition time was eight hours per night. Data were obtained from summer to fall in 2016-2017. Simultaneously, during trap placing and monitoring, visual encounter surveys were conducted with flashlights. These surveys were limited to places with visible shelters or burrows and on stream/reservoir bottoms. Visual surveys were conducted by one or two people. Further, the success of visual encounter surveys and the trapping approach was compared. Additionally, the overlap between visual encounters and trapping was assessed, i.e., the number of instances when trapping and visual inspection detected the species and cases when the results of these two methods differed were compared.

\section{Orconectes limosus}

In summer and fall 2018, stagnant waterbodies including natural, postglacial lakes (north-central Poland) and artificial reservoirs (south-central and central Poland), were studied (see Table 2 for locations). The sites were inspected after sunset in the shallow parts of each reservoir. The surveys were concluded after 30 minutes or when we detected the first spiny-cheek crayfish. Each of the three visits targeted easily accessible sites (parts of the shoreline with non-vegetated bottoms and surfaces), but when these areas were small, the reed-covered parts of the shoreline were also assessed.

\section{Results}

\section{Astacus astacus trapping and visual encounter surveys}

In total, 27 sites were inspected (Table 1). The ratio of detection to non-detection was 0.5 for the trapping method and 0.8 for visual observation. The slightly higher effectiveness of the visual encounters was insignificant (Fisher's exact two tailed probability test: $\mathrm{P}=0.58$ ). In most cases (24 sites), the results for trapping and visual search were the same (presence vs. presence or absence vs. absence).

\section{Orconectes limosus detection time}

The spiny-cheek crayfish was detected in 12 of the 17 investigated waterbodies (Table 2). It took from 1 to $22 \mathrm{~min}$ to detect the crayfish. The modal value for detection time at all sites and all sampling dates was 2 min. In some cases (approx. 11\%), crayfish were detected in the first minute of the survey (Table 2) (Fig. 1). The mean (and median) time of detection lengthened gradually from the first to the third survey 
Table 1

Presence (1) and absence (0) data for trapping and active visual observation of the noble crayfish, Astacus astacus. Catch per unit effort (CPUE) for trapping is shown. Exact location is not given to mitigate potential poaching (locations are available from the Chief Inspectorate of Environmental Protection)

\begin{tabular}{|c|c|c|c|}
\hline Site id. & CPUE & Traps & Visual Sampling \\
\hline 1 - river & 0 & 0 & 0 \\
\hline 2 - river & 0 & 0 & 0 \\
\hline 3 - stream & 0 & 0 & 0 \\
\hline 4 - stream & 0 & 0 & 0 \\
\hline 5- stream & 0 & 0 & 0 \\
\hline 6 - stream & 0 & 0 & 0 \\
\hline 7- stream & 0 & 0 & 0 \\
\hline 8 - stream & 0 & 0 & 0 \\
\hline 9 - stream & 0 & 0 & 0 \\
\hline 10 - stream & 0 & 0 & 0 \\
\hline 11- quarry & 0 & 0 & 0 \\
\hline 12 - excavation & 0 & 0 & 0 \\
\hline 13 - quarry & $>1$ & 1 & 1 \\
\hline 14 - stream & 1.6 & 1 & 1 \\
\hline 15 - stream & 4.2 & 1 & 1 \\
\hline 16 - stream & 0.1 & 1 & 1 \\
\hline 17 - stream & 0 & 0 & 1 \\
\hline 18 - river & 0 & 0 & 1 \\
\hline 19 - stream & $>0.5$ & 1 & 1 \\
\hline 20 - river & 0.6 & 1 & 1 \\
\hline 21 - stream & $>1$ & 1 & 1 \\
\hline 22 - stream & 0 & 0 & 1 \\
\hline 23 - stream & 0 & 0 & 0 \\
\hline 24 - lake & 4.2 & 1 & 1 \\
\hline 25 - stream & 1.2 & 1 & 1 \\
\hline 26 - stream & 0 & 0 & 0 \\
\hline 27 - excavation & 0 & 0 & 0 \\
\hline Sum of 'presence' observations & & 9 & 12 \\
\hline
\end{tabular}

(Table 2, Fig. 1); however, the differences were insignificant (Kruskal-Wallis test: $\chi^{2}=1.87$, df $=2, \mathrm{P}=$ 0.39). In terms of presence/absence, there was $100 \%$ agreement between the first and second survey. During the third survey, crayfish were not detected at two sites $(12 \%)$ despite being detected on two previous occasions. The absence of crayfish in five waterbodies was confirmed in all three consecutive surveys. Sample rarefaction showed that one survey covered $11.33(\mathrm{SD}=0.43)$ of a maximum of $12 \mathrm{de}-$ tections per survey.

\section{Discussion}

The effectiveness of crayfish visual encounter surveys vs. other methods have not been compared to

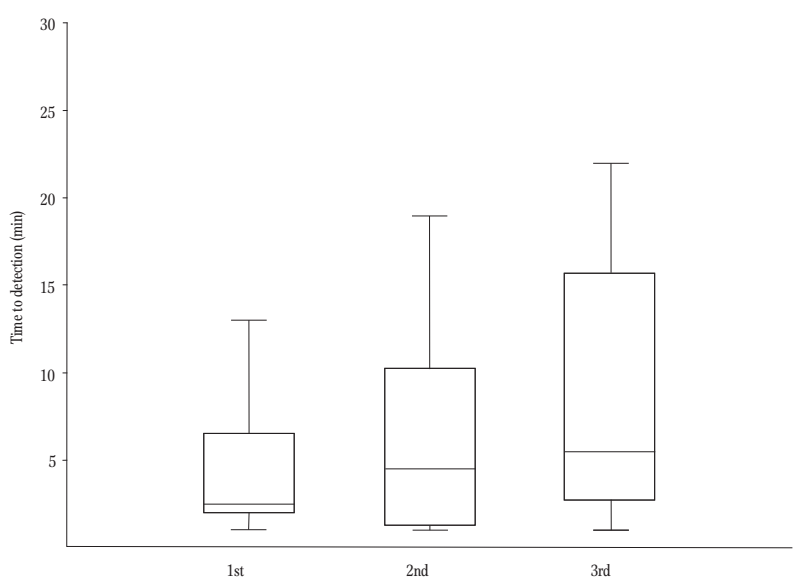

Figure 1. Median time until the first detection of O. limosus during three surveys. Boxes show standard errors and whiskers show the time range.

date. Reynolds et al. (2010) compared the practical advantages of visual encounter surveys with other commonly used methods of crayfish sampling. 
Table 2

Presence (1) and absence (0) data, date, and time (min) until the detection of the first Orconectes limosus individual in stagnant waters, and waterbody characteristics. Area is in hectares

\begin{tabular}{|c|c|c|c|c|c|c|c|c|c|c|c|c|}
\hline \multirow[b]{2}{*}{ Site name } & \multirow[b]{2}{*}{ Location } & \multirow[b]{2}{*}{ Origin } & \multirow[b]{2}{*}{ Area } & \multicolumn{3}{|c|}{ Control date } & \multicolumn{3}{|c|}{$\begin{array}{l}\text { Presence ab- } \\
\text { sence }\end{array}$} & \multicolumn{3}{|l|}{ Time } \\
\hline & & & & $\mathrm{i}$ & ii & iii & $\mathrm{i}$ & ii & iii & $\mathrm{i}$ & ii & iii \\
\hline $\begin{array}{l}\text { Wikaryjskie } \\
\text { Lake }\end{array}$ & $\begin{array}{l}52.604622^{\circ} \mathrm{N} \\
19.123320^{\circ} \mathrm{E}\end{array}$ & natural & 51.5 & 2018.06.03 & 2018.08.11 & 2018.11.01 & 1 & 1 & 0 & 3 & 12 & na \\
\hline Kryspinów & $\begin{array}{l}50.050837^{\circ} \mathrm{N} \\
19.788228^{\circ} \mathrm{E}\end{array}$ & anthropogenic & 40 & 2018.06.08 & 2018.07.20 & 2018.10 .04 & 1 & $1^{*}$ & 0 & 2 & 5 & na \\
\hline $\begin{array}{l}\text { Lubiechowskie } \\
\text { Lake }\end{array}$ & $\begin{array}{l}52.547797^{\circ} \mathrm{N} \\
19.253799^{\circ} \mathrm{E}\end{array}$ & natural & 16 & 2018.06.03 & 2018.08.11 & 2018.11.01 & 1 & 1 & 1 & 1 & 3 & 12 \\
\hline Skrzynki Lake & $\begin{array}{l}52.524601^{\circ} \mathrm{N} \\
19.322297^{\circ} \mathrm{E}\end{array}$ & natural & 25 & 2018.06.03 & 2018.08.11 & 2018.11.01 & 1 & 1 & 1 & 2 & 19 & 4 \\
\hline Przylasek & $\begin{array}{l}50.048405^{\circ} \mathrm{N} \\
20.160138^{\circ} \mathrm{E}\end{array}$ & anthropogenic & 19 & 2018.06.07 & 2018.07.19 & 2018.10 .04 & 1 & $1^{*}$ & 1 & 13 & 4 & 18 \\
\hline $\begin{array}{l}\text { Wióry } \\
\text { Reservoir }\end{array}$ & $\begin{array}{l}50.946181^{\circ} \mathrm{N} \\
21.169768^{\circ} \mathrm{E}\end{array}$ & anthropogenic & 300 & 2018.07.22 & 2018.09.26 & 2018.10 .08 & 0 & 0 & 0 & na & na & na \\
\hline $\begin{array}{l}\text { Borków } \\
\text { Reservoir }\end{array}$ & $\begin{array}{l}50.775408^{\circ} \mathrm{N} \\
20.759704^{\circ} \mathrm{E}\end{array}$ & anthropogenic & 38 & 2018.06.16 & 2018.07.23 & 2018.10 .08 & 1 & 1 & 1 & 2 & 5 & 1 \\
\hline Golejów & $\begin{array}{l}50.555175^{\circ} \mathrm{N} \\
21.217658^{\circ} \mathrm{E}\end{array}$ & anthropogenic & 5.5 & 2018.06.15 & 2018.07.23 & 2018.10 .09 & 1 & 1 & 1 & 5 & 1 & 7 \\
\hline Połaniec & $\begin{array}{l}50.441505^{\circ} \mathrm{N} \\
21.262344^{\circ} \mathrm{E}\end{array}$ & anthropogenic & 3 & 2018.06.16 & 2018.09.27 & 2018.10 .09 & 0 & 0 & 0 & na & na & na \\
\hline $\begin{array}{l}\text { Skalbierz } \\
\text { Reservoir }\end{array}$ & $\begin{array}{l}50.327400^{\circ} \mathrm{N} \\
20.397814^{\circ} \mathrm{E}\end{array}$ & anthropogenic & 8.5 & 2018.06.07 & 2018.07.19 & 2018.10 .07 & 0 & $0^{*}$ & 0 & na & na & na \\
\hline $\begin{array}{l}\text { Kazimierza } \\
\text { Wielka } \\
\text { Reservoir }\end{array}$ & $\begin{array}{l}50.263813^{\circ} \mathrm{N} \\
20.477810^{\circ} \mathrm{E}\end{array}$ & anthropogenic & 21.5 & 2018.07.19 & 2018.08.31 & 2018.10 .07 & $0^{*}$ & $0^{*}$ & 0 & na & na & na \\
\hline Dąbie Pond & $\begin{array}{l}50.065248^{\circ} \mathrm{N} \\
19.986981^{\circ} \mathrm{E}\end{array}$ & anthropogenic & 2.5 & 2018.07.21 & 2018.09.06 & 2018.10 .04 & 0 & 0 & 0 & na & na & na \\
\hline $\begin{array}{l}\text { Borzymowskie } \\
\text { Lake }\end{array}$ & $\begin{array}{l}52.488269^{\circ} \mathrm{N} \\
18.995411^{\circ} \mathrm{E}\end{array}$ & natural & 167.5 & 2018.06.03 & 2018.08.12 & 2018.11.01 & 1 & 1 & 1 & 5 & 5 & 22 \\
\hline $\begin{array}{l}\text { Lubieńskie } \\
\text { Lake }\end{array}$ & $\begin{array}{l}52.408212^{\circ} \mathrm{N} \\
19.170790^{\circ} \mathrm{E}\end{array}$ & natural & 88.5 & 2018.06.03 & 2018.08.11 & 2018.11.01 & 1 & 1 & 1 & 7 & 17 & 15 \\
\hline Łuba Lake & $\begin{array}{l}52.633494^{\circ} \mathrm{N} \\
19.010120^{\circ} \mathrm{E}\end{array}$ & natural & 11 & 2018.06.03 & 2018.07.07 & 2018.11.01 & 1 & 1 & 1 & 2 & 1 & 2 \\
\hline $\begin{array}{l}\text { Mostki } \\
\text { Reservoir }\end{array}$ & $\begin{array}{l}51.060458^{\circ} \mathrm{N} \\
20.909800^{\circ} \mathrm{E}\end{array}$ & anthropogenic & 22 & 2018.07.24 & 2018 & 2018.10 .08 & 1 & 1 & 1 & 7 & 2 & 3 \\
\hline \multirow[t]{4}{*}{$\begin{array}{l}\text { Cedzyna } \\
\text { Reservoir }\end{array}$} & $\begin{array}{l}50.871865^{\circ} \mathrm{N} \\
20.725719^{\circ} \mathrm{E}\end{array}$ & anthropogenic & 54 & 2018.06.16 & 2018.07.22 & 2018.10 .08 & 1 & 1 & 1 & 1 & 1 & 3 \\
\hline & & & & & & Mean (SE) & & & & $\begin{array}{l}4.2 \\
(1.84)\end{array}$ & $\begin{array}{l}6.3 \\
(2.50)\end{array}$ & $\begin{array}{l}8.7 \\
(2.74)\end{array}$ \\
\hline & & & & & & Modal value & & & & 2 & 5 & 3 \\
\hline & & & & & & $\begin{array}{l}\text { Median } \\
\text { value }\end{array}$ & & & & 2.5 & 4.5 & 5.5 \\
\hline
\end{tabular}

* Two persons participated in this survey 
Moreover, they used night surveys to provide indirect (catch per unit effort; CPUE) abundance data, but they did not compare the efficiency of various methods. These studies were conducted for Autropotamiobius paliipes (Lereboullet) in Ireland. Marzec and Okrąła (2018) also found in their studies that night surveys were more effective than trapping (Pacifastacus leniuscuslus (Dana) and $O$. limosus) in postglacial lakes in Poland. However, since comparing these methods was not the target of the study, no information on the visual survey effort is provided. With A. astacus, which is surveyed mostly in watercourses, visual encounter surveys are at least as effective when assessing the presence of the species as is the trapping method. A slightly higher ratio of positive detections, although statistically insignificant, indicates that this method might outperform standard trapping. However, this requires further research.

Considering the costs, labor, and time needed to conduct crayfish detection using traps, visual encounter surveys are a better solution for studies requiring presence/absence data from numerous sites. In the authors' experience, a survey effort of several minutes is often enough to detect the first crayfish in small streams. Even 2 to $3 \mathrm{~h}$ of visual monitoring in a $1 \mathrm{~km}$ section of a stream is still much less than the eight hours or more required to conduct passive trapping (Strużyński 2015). On the other hand, traps can still be a better solution when abundance data are necessary. Crayfish are also much more difficult to detect in deeper and/or turbid waters; thus, the visual encounter method can be recommended mostly for shallow, relatively clear watercourses. This method is also probably more influenced by surveyor skills and experience. O. limosus can also be effectively sampled by visual encounters. According to the observations presented herein, one monitoring survey is usually sufficient to detect this species as it was typically detected after several minutes of inspection. However, fall water cooling can decrease the probability of detection because of declining crayfish activity as the temperature of the water drops and the season progresses; however, this does not stem from a decrease in the effectiveness of the detection method itself. According to the data presented, false absences were detected in fall at sites where the species had been recorded earlier in the season. The mean detection time tended to increase later in the season, but it was not significant. However, this could have resulted from random reasons because of the relatively small number of sites surveyed. Holdich and Black (2007) found that the most effective trapping period of $O$. limosus in the UK is late summer and fall. This could be caused by higher foraging and/or breeding activity and also higher detection probability with baited traps. Most probably, false non-detection in our study could have stemmed from local, short-term factors such as weather conditions.

Visual encounter surveys have many limitations (i.e., water depth and turbidity, surveyor skills). They also do not provide population size estimates at given sites. On the other hand, they may be less dependent on the foraging intensity of crayfish and much more useful for large scale inventories of both endangered $A$. astacus, invasive O. limosus, and also, most probably, other crayfish. Further studies on larger samples (both the number of sites and the number of surveys) that focus on the relationship between detection time and population abundance would verify whether this method is useful for population abundance estimations.

Acknowledgements. We would like to thank Andrzej Antoł, Monika Bobrek, Joanna Przybylska, Roman Maniarski, and Mariusz Gwardjan for their help in fieldwork. Data for $A$. astacus were obtained during national monitoring conducted by the Chief Inspectorate of Environmental Protection and funded by the National Fund for Environmental Protection and Water Management. The Institute of Nature Conservation, PAS, coordinates this project.

Author contributions. M.B. - conceptualization, field surveys, data analysis, manuscript writing and editing; R.B. - field surveys, manuscript comments and writing; J.D. - field surveys; W.S. - field surveys, manuscript comments. 


\section{References}

Ahmadi M. 2016 - The Feasibility of Electrotaxis and Phototaxis in American Crayfish - Improved Experimental Designs. Lambert, Academic Publishing.

Alonso F. 2001 - Efficiency of electrofishing as a sampling method for freshwater crayfish population in small creeks - Limnetica 20: 59-72.

Dorn N.J., Urgelles R., Trexler J.C. 2005 - Evaluating active and passive sampling methods to quantify crayfish den-

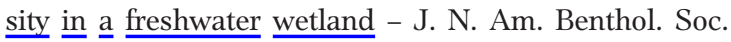
24:346-356.

Green N., Bentley M., Stebbing P., Andreou D., Britton R. 2018 - Trapping for invasive crayfish: comparisons of efficacy and selectivity of baited traps versus novel artificial refuge traps - Knowl. Manag. Aquat. Ecosyst. 419: 15.

Holdich D., Black J. 2007 - The spiny-cheek crayfish, Orconectes limosus (Rafinesque, 1817) [Crustacea: Decapoda: Cambaridae], digs into the UK - Aquat. Invasions 2: 1-15.

Marzec M., Okrągła I. 2018 - Crayfishes in selected lakes of the Suwalski Landscape Park - Przegl. Przyr. 3: 100-106 (in Polish with an English summary).

Nowicki P., Tirelli T., Sartor R.M., Bona F., Pessani D. 2008 Monitoring crayfish using a mark-recapture method: potentials, recommendations, and limitations Biodivers. Conserv. 17: 3513-3530.

Pilotto F., Free G., Crosa G., Sena F., Ghiani M., Cardoso A.C. 2008 - The invasive crayfish Orconectes limosus in Lake Varese: estimating abundance and population size structure in the context of habitat and methodological constraints - J. Crust. Biol. 28: 633-640.

Price J.E., Welch S.M. 2009 - Semi-quantitive methods for crayfish sampling: sex, size and habitat bias - J Crust. Biol 29: 208-216.

Rabeni C.F., Collier K.J., Parkyn S.M., Hicks B.J. 1997 - Evaluating techniques for sampling stream crayfish (Paranephrops planifrons) - New. Zeal. J. Mar. Fresh. 31: 693-700.

Reynolds J., O’Connor W., O’Keeffe., Lynn D. 2010 - A technical manual for monitoring white-clawed crayfish Austropotamobius pallipes in Irish lakes - Irish Wildlife Manuals No. 45. Environment, Heritage and Local Government.

Strużyński W. 2015 - The noble crayfish, Astacus astacus (Linnaeus, 1758) - In: Monitoring Animal Species. A Practical Guide. Part IV (Eds) M. Makomaska-Juchiewicz, M. Bonk, Biblioteka Monitoringu Srodowiska, Warszawa: 262-280 (in Polish). 